$\mathrm{V} \Delta \mathrm{K} 342$

ББК 67.400

DOI 10.22394/1682-2358-2020-5-67-73

U.A. Starshova, Candidate of Sciences (Law), Docent of the Constitutional Law Department, Saratov State Academy of Law

\section{SOCIAL STATE DEVELOPMENT IN CONTEMPORARY RUSSIA}

Foreign experience of social state formation is considered. The current stage of development of the social state in Russia is studied. Special attention is drawn on the amendments to the Constitution of the Russian Federation in this area.

Key words and word-combinations: social state, social policy, minimum wage, amendments to the Constitution of the Russian Federation.
У.A. Стариова, кандидат юридических наук, дочент кафедри конституционного права Саратовской государственной юридической академии (email: Starshova@yahoo.com)

\section{РАЗВИТИЕ СОЦИААЬНОГО ГОСУААРСТВА В СОВРЕМЕННОЙ РОССИИ}

Аннотащия. Рассматривается зарубежный опыт становления социального государства. Исследуется современный этап развития социального государства в России. Особое внимание уделяется поправкам в Конституцию РФ в данной cфере.

Ключевые слова и словосочетания: социальное государство, социальная политика, МРОТ, поправки в Конституцию РФ.

3

акон о поправке в Конституцию Российской Федерации, принятый Государственной Аумой, одобренный Советом Федерации 11 марта 2020 г. и утвержденный большинством россиян 1 июля 2020 г., опреАелил в числе прочих Аополнений новый вектор развития закрепленного в ст. 7 Конституции России 1993 г. принщипа соџиального государства. Аанный принцип стал наполняться реальным конституционным содержанием. Переход от некой конституционной Аекларативности закрепления очевиден. В настоящее время момент формируется концепџияреализаџиисоциацьногогосударства, начало которой положии Президент РФ 
еще в своем Послании Федеральному Собранию РФ от 20 феврамя 2019 г., обозначив задачи современной государственной социальной политики. Это всемерная поддержка семьи, детства, повышение уровня здравоохранения и доступность медиџинской помощи, решение проблемы бедности [1] . В обращении к Федеральному Собранию РФ 15 января 2020 г. все эти идеи стали основными и были предложкены в качестве основополагающих поправок в Конституџию Российской Федерации.

Следовательно, можно предполагать, что данные поправки приблизят российское общество к реализаџии конџепции соџиального государства, заложенного еще в 1993 г. Конституџией РФ. ОАнако реализации предлагаемых новшеств на практике предстоит сложный путь.

Сегодня созрела необходимость формулирования государственной доктрины или концепции реализации принципа социального государства, основой которой явмяется реальная цель - социальное благополучие граждан России. Аанная доктрина Аолжна строиться на основе принџипа создания условий Амя устойчивого экономического роста страны и повышения благосостояния граждан, дия взаимного доверия государства и общества, что непосредственно закрепляется в Законе РФ о поправке к Конституции РФ от 14. марта 2020 г. № 1-ФКЗ «О совершенствовании регулирования отдемьных вопросов организации и функционирования публичной власти».

Становление и развитие идеи соџиального государства в мире происходицо сложным путем. В Великобритании зачатки соџиальной государственности и некоторое их закрепление в нормативных актах можно найти уже в Великой хартии вольностей 1215 г. В США в Аекларации прав ВирАжинии от 12 июня 1776 г. наряду с правом каждого на счастье и безопасность формулируется обязанность правительства содействовать всеобщему благополучию и обеспечивать высшую степень счастья и безопасность.

В мировой мысли идея социальной государственности находит выражение в двух основных концепциях. Аیя обозначения данного феномена в англоязычном мире используется понятие «welfare state», что в переводе звучит как «государство всеобщего бцагосостояния», «государство всеобщего благоденствия». Аанное определение возникло в Великобритании во время Второй мировой войны в противовес гитлеровскому «warfare state» - «государству войны». Аругая тенденция развития соџиального государства относится к континентальной Европе. В государственном праве Германии более распространен термин «соџиальное правовое государство».

Особым примером закрепления принципа правового соџиамьного государства явмяется ФРГ, где в Основном законе страны 1949 г. Аанный принцип содержится в ч. 1 ст. 20, ч. 1 ст. 21-2, ч. 1 ст. 28.

В исследовании правового социального государства в ФРГ особую роль сыграл видный немецкий ученый К. Хессе, который отмечал, что основные социальные права в силу их специфики имеют иную структуру, чем классические основные права, и реализуются по-иному - не благодаря 
тому, что уважаются, но потому, что требуют государственного вмешательства с целью осуществления социальных программ, для реализации которых необходима постоянная деятельность не только законодателя, но и органов управления. Конституџия предусматривает Аля их решения, помимо обычного, и иной путь - нормирование государственной деятельности, что выражкается формулой «соџиального правового государства» [2, c. $108-116]$

Констатаџия правовой природы соџиального государства фактически закрепила за государством его соџиальные функции. Соџиальные права стали основными дмя государства, а социальная функция государства обрела правовою основу. На наш взгляА, правовое соџиальное государство обязуется выполнять свою соџиальную функщию, что означает ответственность в Аанной сфере не только обшества, но и государства.

Сегодня в Германии происходит систематизация соџиальных законов в так называемый Кодекс социального обеспечения (Социальный кодекс) - SGB, который состоит из нескольких частей, регулирующих общие вопросы об индивидуальных выплатах, обязательное медицинское страхование, обязательное пенсионное обеспечение и другое.

Конституционное право Франции также закрепляет соџиальное госуАарство, например в ст. 1 Конститущии Французской Республики говорится о том, что «Франџия является неделимой, светской, демократической и соџиальной Республикой...». Кодекс соџиального обеспечения Франции - весьма подробный юридический документ, который закрепцяет положения о соџиальном страховании, семейные пособия, пособия по соџиальному жилью и т.п. Различные нормативно-правовые акты Франции кодифицированы в этом документе: декреты Правительства, декреты Государственного совета Франщии и Аругие.

На наш взгляА, сегодня можно заявлять о понимании соџиального госуАарства в нескольких аспектах (плоскостях): как об идее, которая получима свое воплощение в трудах различных ученых; как об конституционном принџипе, основе конституџионного строя разАичных государств мира; как о качественной государственной соџиальной политике, направленной на повышение благосостояния граждан. Поскольку достижение конституционного принципа соџиального государства невозможно без действенной социальной политики, то необходима некая ее «конституционализация», то есть непосреАственное влияние конституционной конџепџии соџиального государства на основные направления соџиальной политики. Соџиальная политика Аолжна способствовать правовой реализаџии соответствующих социальных гарантий, закрепленных в Конституции РФ (конституционных гарантий). Некоторые ученые утверждают, что реальная конституционализация социальной политики станет большим шагом впереА на пути становления соџиального государства в России [3, с. 8] . Аیя этого необхоАимо принятие комплексного правового акта - Концепции (Аоктрины) 
развития соџиального государства России, который предопределит Стратегию развития Российской Федерации в Аанной сфере.

После одобрения поправок в Конституџию РФ В.В. Путин подписал Указ «О национальных целях развития Российской Федерации на периоА до 2030 года». Аанный нормативный акт определил цели наџионального развития: благополучие и здоровье мюдей, безопасность и комфорт гражАан, возможности Аля развития талантов кажАого, Аостойный труА, успешная преАпринимательская деятельность, цифровое государство. Перечисленные направления, как преАставляется, Аолжны составить основу современной социальной политики [4] .

Защита материнства, отцовства и детства также является одной из основных целей соџиальной политики современного государства. Государственная поддержка семьи, материнства, отцовства и детства закрепляется ч. 2 ст. 7 Конституции РФ и развивается в отраслевом законодательстве. Аанный принцип отражкается и в поправках в Конституцию РФ. Так, ч. 1 ст. 72 дополнена новым пунктом «Ж (1)» - «защита семьи, материнства, отцовства и детства; защита института брака как союза мужчины и женщины; создание условий Аля достойного воспитания детей в семье, а также Аля осуществления совершеннолетними детьми обязанности заботиться о родителях». Государство должно создавать необходимые условия

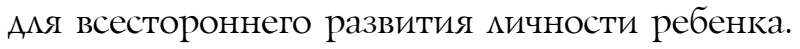

ОАним из необходимых направлений современной концепџии соџиального государства в России должно стать повышение качества и уровня образования, необходим возврат от так называемых «образовательных ускуг» к качественной системе образования, которая будет работать именно как система, внутри которой соблюдается переход от одного звена образования к последующему, при этом необходимо развивать и дополнительное образование. К примеру, в 1990-х годах в Норвегии была благополучно проведена реформа образования, в результате которой коммективные цели и принципы преподавания в начальной и средней школе определены в Национальном учебном плане страны. Аанные принципы содержат общее описание, обязательное для всех учеников, но в каждой местности возможна некая корректировка под местные условия жизни конкретного региона. Подобная свобода действия муниџипалитетов преАставцяется положительным фактором Аля приближения процесса школьного обучения к реалиям данной местности с ее традиџиями и экономикой $[5$, c. $33-34]$.

В современных условиях в России развитие общественных отношений в Аанной сфере регламентировано Федеральным законом «Об образовании в Российской Федераџии» от 21 декабря 2012 г. № 273-Ф3. В нем закреплены социально-экономические и организаџионно-правовые основы образования, принџипы государственной политики России в этой области, общие правила функционирования образовательной системы и осущест- 
вления образовательной деятельности [6]. При этом законодатель рассматривает образование как единую целостную систему с компонентами воспитания и обучения, направленную на развитие человеческого капитама и обшества. В целом это соответствует традиционному миберальному европейскому подходу к образованию.

Абсолютно правильным представмяется на государственном конституционном уровне закрепить минимальный размер оплаты труда не менее величины прожиточного минимума. Прожиточный минимум можно назвать «официальным порогом бедности» в Российской Федерации. Он рассчитывается на основе стоимости потребительской корзины. Вемичина потребительской корзины опредемяется стоимостью жизненных средств, необходимых аля нормального воспроизводства способности к труду в Аанных общественно-экономических условиях [7, с. 92]. ОАнако закрепить МРОТ не ниже прожиточного минимума - это меньшее, что может сделать государство Аля обеспечения достаточной жкизни сегодня. В Саратовской области векичина прожиточного минимума за четвертый квартал 2019 г. установлена на Аушу трудоспособного населения в размере 9509 руб., на детей - 8964 руб. [8].

Важнейшей целью соџиального государства является осуществление правомочий мичности, связанных с правом на достойную жизнь (ст. 7 Конституции РФ). В контексте развития соџиальной государственности это наиболее значимая задача. В отечественном правоведении эта проблема активно разрабатывацась известным дореволюџионным юристом П.И. Новгородџевым в работе «Право на достойное человеческое существование» [9, с. 448]. Право на достойное существование в начале XX в. понималось не как идеал человеческой жизни, а как необходимый минимум социальных благ, без которых человек чувствует себя ущербно. Обеспечение этого минимума благ должно взять на себя государство на основе права.

ОАнако Аостаточный уровень жизни далеко не всегда тождествен Аостойной. Реализаџия и обеспечение «права на достойную жизнь, которое вытекает из сущности ст. 7 Конститущии РФ, представцяется наиважнейшим фактором достижения соџиального государства.

Сушествует целый ряд международно-правовых норм, которые опредемяют понятие «достойный уровень жкизни». Так, Международный пакт об экономических, соџиальных и культурных правах 1996 г. признал право каждого человека на Аостойный уровень жизни, вкмючая соџиальное страхование, а также право на достаточный уровень жизни дяя него и его семьи. В понятие «достаточный уровень жизни» данный документ включает достаточное питание, одежАу и жилище. Понятие «достойный уровень жизни» преАставмяется более точным и преАпочтительным, чем понятие «достаточный жизненный уровень». Аостойная жизнь - понятие более широкое и, кроме материального обеспечения и соџиальных благ современной цивилизации (жилище, питание, одежда и т.п.), преАполагает 
свободное развитие человека - физическое, умственное, нравственное совершенствование. А.С. Велиева совершенно справедливо утверждает также важность признания на конституционном уровне права на достойный уровень жкизни экологической составмяющей [10, с. 80].

Некоторые ученые считают, что достойный уровень жизни - это некий индикатор уровня жкизни, ориентир, к которому следует стремиться [11, с. 197]. ОАнако, на наш взгляд, Аостойная жизнь человека должна рассматриваться как основное право, закрепленное на конституџионном уровне, которое реализуется и гарантируется государством. Как и Аругие социально-экономические права, закрепленные в Конституции РФ, право на достойную жкизнь требует от государства определенной деятельности, усилий. Б.С. Эбзеев отмечает, что соџиально-экономические права и свободы содержат в себе обширную соџиальную программу, требующую дия своей реализации положительных усилий государства [12, с. 226]. В итоге соџиальное государство, основная задача которого - создание условий и ответственность за реализацию права человека на достойную жизнь, оказывает самое непосредственное воздействие на осушествление единого компиекса прав и свобод человека.

Свободное развитие подразумевает свободный доступ и возможноость получения должного образования, выбора трудовой Аеятельности, посещение культурных объектов и многое Аругое.

Некоторые ученые полагают, что все конституционные права и свободы определяют возможности свободного развития человека [13]. ОАнако социально-экономические права наполняют данную цель соџиального государства истинным содержанием. Тем не менее немьзя возлагать обеспечение достойной жизни человека и его свободное развитие только на государство. Излишняя забота государства о своих гражданах может привести к снижению активности населения, отсутствию необходимости работать и зарабатывать и, возможно, соџиальному иждивенчеству. Излишняя государственная поддержка в виде различных пособий порождает пассивность насемения, зависимость от государственных выпцат, которые на достаточном уровне обеспечивают жизнь гражданина.

Кроме непосредственной роли государства в обеспечении данного права, Конституџия РФ, закрепляя соџиально-экономические права, предоставцяет возможность гражданину обеспечить достойный уровень жизни Аля себя и своей семьи. Этому способствует свобода экономической деятельности, в том числе преАпринимательская, зрелое гражданское общество, свобода творчества, частная собственность. Еще в 2016 г. Конституционный СуА РФ охарактеризовал Российскую Федераџию как государство с «социально ориентированной рыночной экономикой» [14], преАставляющей собой фундамент Амя построения сощиального государства.

Аостойная жизнь и свободное развитие человека не должны обеспечиваться только на основе прямого регулирования - установмения пенсий,

72 Bulletin of the Volga Region Institute of Administration • 2020. Vol. 20. № 5 
пособий, страховых взносов. Новой особенностью развития социальной функции государства явмяется использование методов косвенного регулирования, например налоговые мьготы или налоговые каникулы, иные меры государственного стимулирования социальных программ частного бизнеса [15, с. 481-482]. Актуальность данные меры приобретают в период пандемии. Государство предмагает конкретные программы подАержки малого и среднего бизнеса: выделение субсидий, налоговые каникулы, оказание профессиональных консультаций, переподготовку специалистов и Аругие инициативы.

\section{Библиографический список}

1. Послание Президента Федеральному Собранию РФ от 20 февр. 2019 г. URL: http:// www.kremlin.ru/acts/bank/44032

2. Хессе К. Основы конституционного права ФРГ. М., 1981.

3. Граф М.Н. Права граждан как элемент конституционной концепции социальной государственности России: автореф. дис. ... канд. юрид. наук. Челябинск, 2007.

4. О национальных целях развития Российской Федерации на период до 2030 года: Указ Президента РФ от 21 июля 2020 г. № 474. URL: www.kremlin.ru/events/president/ news $/ 63728$

5. Тевлина В.В. Научно-образовательная политика в Норвегии: национальные и общемировые тенденции развития // Вестник Северного (Арктического) федерального университета. Сер.: Гуманитарные и социальные науки. 2012. № 2.

6. СЗ РФ. 2012. № 53. Ст. 7558; 2014. № 19. Ст. 2289; № 30. Ст. 4257; 2015. № 1. Ст. 42; 2017. № 50. Ст. 7563.

7. Станишевская С.П., Губанов Д.А. К вопросу о российской потребительской корзине // Вестник Пермского государственного университета. Сер.: Экономика. 2012. № 2.

8. О величине прожиточного минимума на душу населения и по основным социально-демографическим группам населения Саратовской области за IV квартал 2019 года: постановление Правительства Саратовской области от 21 февр. 2020 г. № 105-П. URL: social.saratov.gov.ru

9. Новгородиев П.И. Сочинения. М., 1995.

10. Велиева Д.С. Проблемы конституционной концептуализации понятия «достойная жизнь» // Ленинградский юридический журнал. 2014. № 2(36). С. 74-84.

11. Павлова И.Д. Конщепция достойного уровня жизни населения в России // Известия высших учебных заведений. Поволжский регион. Общественные науки. 2015. № 2(34). С. 194-203.

12. Эбзеев Б.С. Конституционное право России: учебник. М., 2019.

13. Киреев B.B. Свободное развитие человека и государственное принуждение в контексте совершенствования положений Конституции РФ // Вестник Челябинского государственного университета. 2010. № 9 (190). Сер.: Право. Вып. 23. С. 5-8.

14. По делу о проверке конституционности пункта 1 части 8 статьи 14 Федерального закона «О страховых взносах в Пенсионный фонд Российской Федерации, Фонд социального страхования Российской Федерации, Федеральный фонд обязательного медицинского страхования» и статьи 227 Налогового кодекса Российской Федерации в связи с запросом Кировского областного суда: постановление Конституционного Суда Российской Федерации от 30 нояб. 2016 г. № 27-П // Вестник Конституционного Суда РФ. 2017. № 2.

15. Алебастрова И.А. Конституционализм как правовое основание социальной солидарности. М., 2016. 